\title{
The Role of Indonesian Trilingual Schools In Social Integration And Cultural Inheritanic (Based On A Survey Of Chinese Descent Students In The Trilinguan Schools)
}

\author{
Yiping Chen ${ }^{1}$, Caiyu LI², Yudi Sutanto ${ }^{3}$ \\ \{tchenyp@jnu.edu.cn ${ }^{1}, 834631744 @ q q$. com $^{2}$ \}
}

\begin{abstract}
(Vice Dean, Professor, School of International Studies \&Academy of Overseas Chinese Studies, Jinan University, Guangzhou, China ${ }^{1}$, School of International Studies \&Academy of Overseas Chinese Studies, Jinan University, Guangzhou, China ${ }^{2}$, President of Indonesian Trilingual School Association, Chair of the Putera Harapan Banyumas (Puhua) Foundation ${ }^{3}$ )
\end{abstract}

\begin{abstract}
During the period of democratic reform in Indonesia, more than 70 trilingual schools have been setup, which reflect the changes in Chinese education in the new era. Based on the questionnaire survey and interview conducted in the trilingual schools, we verified the following research hypothesis: Indonesian trilingual schools(ITS) can play an important role in social integration and cultural Inheritance for the Chinese descent students. We find that (1) multilingual classroom teaching, practical activities and cultural environment influence are the important variables of affecting the integration of the ethnic Chinese into the mainstream and the inheritance of Chinese culture; (2) Chinese descent students have different degrees of integration into the mainstream and cultural inheritance depending on their age, school and region; (3) in general, Chinese descent students learned the mainstream greater than Chinese cultural heritage.
\end{abstract}

Key words: Indonesian trilingual school; integration ;inheritance ;Chinese culture

\section{Introduction}

Chinese descent students are a new force and the future builders of Indonesian Chinese society. Their integration into the mainstream society and the inheritance of Chinese culture are related to the harmony and stability of Indonesia's social order as well as the survival and development of Chinese society. In order to train Chinese descent students as Indonesian nationals with Chinese temperament, the Chinese community has setup more than 70 trilingual schools during the period of democratic reform. The trilingual schools recruit students from ethnic Chinese and other ethnic groups for the education, which provide a platform for the communication and integration of the diverse cultures and different ethnic groups in the new era of Indonesia. 


\section{Literature Review}

Integrating into the mainstream and inheriting national culture is the trend of the development of ethnic Chinese society. John W. Berry attributes the above two dimensions to cultural integration, that is, immigrants are willing to pass on the original culture and interact with other groups in the face of cultural choices[1]. Cultural integration makes the immigration culture local and ethnic, and meets the needs of ethnic Chinese for development. With the rise of multicultural policies, many scholars in China and other countries pay attention to the role of school education in the integration of immigration culture and its ways. As far as the functions of Chinese schools are concerned, most of the articles are carried out from the perspective of nation-state and the overseas Chinese community, reflecting the characteristics of the integration of Chinese schools into the mainstream society and the inheritance of Chinese culture in the new era. Wang Yu and Liu Yan analyzed the functions of school education from the political, economic and cultural aspects. They pointed out that through the development of Chinese education, schools can play an important role in promoting ethnic cohesion, increasing economic development vitality, and improving cultural exchange and creation[2]. From the perspective of ethnology, Liu Yan took the Chonburi community in Thailand as a case study, and explored that Chinese schools are the main driving force for the formation of strong ethnic groups and ethnic cohesion among members of the community. In the learning life of the public school, Buddhism, royal power and Chinese culture interact to shape the social consciousness of community members[3] This highlights the role of school education as a bridge between the Chinese community and the mainstream society. Zhuang Zhihui and Liu Yizhen clearly stated that the task of multicultural education is to cultivate students' Chinese cultural qualities, maintain the friendship between Chinese descent students and other students, and promote culture and information in the world communication with each other[4]. In another article, Liu Yizhen added that education has the functions of transmission, choice, and creation, and promotes Chinese cultural adaptation and cultural construction[5]. As far as the implementation of the cultural integration function of Chinese schools is concerned, the existing literature has been specifically discussed from a micro perspective. Scholars such as Valerie Miller Maloof analyze the school's form of classwork, develop localized textbooks, and conduct extracurricular practice activities to promote interaction between ethnic groups[6]. Guofang Li analyzed the Chinese education in many regions, found that the interesting contents and the pertinence of the teaching material play an important role in multi-teaching. Na Muhan believes that school education is a rational activity carried out in the inheritance of ethnic culture. The article puts forward that the ethnic traditional education needs to pay attention to the openness of the subject of curriculum development, the openness of the content system, the constructiveness of the teaching process and the democratic relationship between teachers and students[7].

In summary, many scholars conducted a lot of valuable qualitative analysis on the cultural function of the Chinese schools, but quantitative analysis is not enough,especially field survey and questionnaire analysis of trilingual schools' role in social integration and cultural inheritance. This paper tries to study the roles and effectiveness of Indonesian trilingual schools in promoting students' integration into the mainstream and cultural heritage based on the field survey and questionnaire conducted in 2018. 


\section{Overview of Indonesian Trilingual Schools}

Indonesian Chinese education has gone through many ups and downs. According to the late professor HUANG Kunzhang of our college, there were not only the private school education and charitable school education before 1901, but also the Chinese education by overseas Chinese from 1901 to 1966 and the Chinese language education later established by the Indonesian Chinese[8]. In the mid-1960s, all ethnic Chinese schools in Indonesia were closed by the government. After the Suharto government stepped down in 1998,Chinese language education was revived.

In order to adapt to the changing situation in the new era of Indonesia and the educational needs of Indonesian Chinese descent students, a new patter of schoolsIndonesian Trilingual Schools were established. The new schools are incorporated into Indonesia national education system, advocating the development of Chinese culture on the premise of integration into the mainstream society through the teaching of three languages (Indonesia, English and Chinese). Up to now, there are more than 70 trilingual schools in Indonesia, and the schools are mainly located in Java and Sumatra. The number of students has reached 50,000-60,000 [9]. With the increase in students' demand for further studies, the schools have expanded to kindergartens, primary schools, and junior high schools. Some trilingual schools have opened high schools. According to the survey of Indonesian Association of Trilingual Schools among the 22 trilingual schools, 54\% schools have offering high school courses[10].

Trilingual schools have made a great contribution to the Indonesia mainstream society and Chinese community. National teaching activities aimed at integrating into the mainstream society help Chinese descent students to form a systematic national outlook and religious beliefs and improve their ability to adapt to the society. In addition, it is an effective way in enhancing ethnic understanding with each other, so that can strengthen ethnic relations. Harmony and mutual assistance relationships are among ethnic groups in trilingual school. More and more students and teachers from different ethnic groups are the indispensable member of the trilingual schools. For example, there are about $20 \%$ students and $52 \%$ Chinese-language teachers from other fraternal ethnic groups in Purwokerto Puhua Trilingual School. As one of the Indonesia national schools, the trilingual schools also share excellent education resources with other national schools, send Chinese teachers (including teachers from fraternal ethnic groups) and carry out Chinese teaching in other national schools, which won praise from the public and government departments.

At the same time, ethnic culture needs to be inherited. The Indonesian Trilingual School is an important part of Chinese education. The philanthropists who invested in the construction of the trilingual school want Chinese descent students to know ethnic roots and cultural origins, enhance the culture identity of the ethnic Chinese community while encouraging Chinese descent students to integrate into mainstream society and culture of Indonesia. Under the guidance of the national education system, schools open Chinese language classes. The teaching language is mainly Indonesian and English, Chinese belongs to the second teaching language. Although Chinese is no longer taught as a mother tongue, it has sufficient class hours to meet the needs of Chinese language learning. According to the criterion by the Indonesian Association of Trilingual Schools, "There are at least four Chinese classes per week, otherwise the school is not in the category of Indonesian trilingual schools." [11]. 


\section{Method for the research}

From the perspective of social integration and cultural inheritance, this paper specifically explores how trilingual schools promote Chinese descent students to integrate into the local society and inherit Chinese culture. In order to verify the hypothesis and viewpoints of this paper, the research uses the questionnaire survey method to analyze the role of trilingual schools. From May to September 2018, the authors went to Java Island, conducted field research in the following schools: Jakarta Pelita school, Jakarta Mulia Bukit Trilingual School, Tangerang Pahoa Trilingual School, Purwokerto Puhua Trilingual School, Magelang Trilingual School, Yogyakarta Budi Utama Trilingual School, Solo Trilingual School, Madiun Mohua Trilingual School and Surabaya Little Sun Trilingual School. The questionnaire is divided into two parts. The first part mainly analyzes the situation of Indonesian trilingual school students' integration into mainstream society from the perspective of national belonging, religious belief ,Indonesian language and culture. The second part is about the students' inheritance of Chinese culture . Combined with the main factors affecting students' cultural adaptation and inheritance, the main influencing factors include classroom teaching, practical activities and campus culture. 900 questionnaires were distributed, 748 valid questionnaires were returned. Among them, there are 233 primary school students, 272 junior high school students, and 129 high school students.

\section{The empirical analysis and key findings}

\subsection{Promoting the Integration of Chinese descent students into the mainstream}

Under the influence of the social environment, the new generation of ethnic Chinese have a tendency to integrate into the mainstream society. As a national school, it systematically promotes the socialization and localization of Chinese. The following is an analysis from the national identity, religious beliefs, language and culture.

\subsubsection{Having a sense of national belonging to Indonesia}

Compared with economic and cultural behaviors, national identity of ethnic minorities is the core of integration. The sense of national belonging is the expression of the national identity sentiment. The attribution of ethnic Chinese to the Indonesian state means that the individual recognizes and accepts Indonesian political ideology and system, is loyal to the Indonesian state. As Indonesian citizens, ethnic Chinese are naturally loyal to Indonesia, fulfill civic obligations as well as enjoy Indonesian citizenship rights. The Indonesian Trilingual Schools provide social education for Chinese descent students, fosters students' national awareness and strengthens students' political identity with Indonesia. 


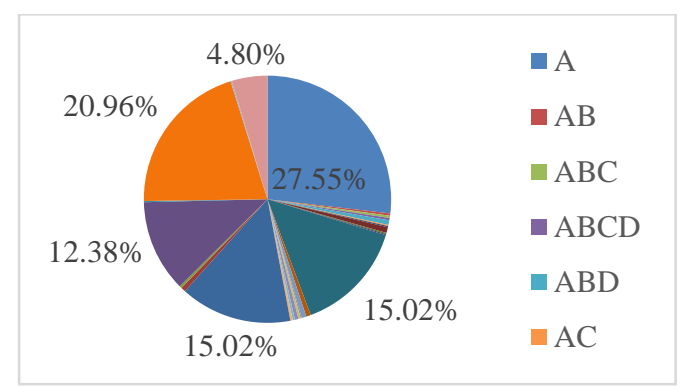

\begin{tabular}{|c|c|c|c|c|c|c|}
\hline $\mathrm{A}$ & $\mathrm{E}$ & $\mathrm{B}$ & $\mathrm{C}$ & $\mathrm{D}$ & other & total \\
\hline $27.55 \%$ & $17.96 \%$ & $15.02 \%$ & $15.02 \%$ & $12.38 \%$ & $12.07 \% \%$ & $100 \%$ \\
\hline
\end{tabular}

Remarks: A, Indonesia; B, China; C, the United States; D, Singapore; E, other

Source: Questionnaire data compiled by the author at the Indonesian Trilingual School in 2018

Fig. 1.Indonesian trilingual school Chinese descent students studying abroad

The students of Indonesian trilingual school have a broad international vision. Under all conditions, different ethnic students have different places of study. However, according to the proportion, most Chinese descent students choose their country-- Indonesia as a place for college study. The destinations for them to study in college are Indonesia $(27.55 \%)$, China $(15.02 \%)$, the United States $(15.02 \%)$, and Singapore $(12.38 \%)$, and other countries $(17.96 \%)$. Objectively speaking, Indonesia's higher education is less developed than the developed countries of the United States and Singapore, but nearly one-third of the students choose Indonesia. It can be seen that Chinese descent students love Indonesia's motherland and have good expectations for Indonesia's future development.

\subsubsection{Piously holding religious beliefs}

Indonesia is a country with a strong religious belief. The government clearly stipulates that Indonesian citizens must believe in religion. As the mainstream ideology of Indonesia, Pancasila first mentions "the supreme God of faith"[12]. Its connotation is practiced in the real life of Indonesian citizens. There are six major religions in Indonesia, all religions enjoy equal status and freedom of belief. Religious piety has become the primary symbol of Indonesian citizens, religious belief is one of the manifestations of ethnic Chinese's integration into society.

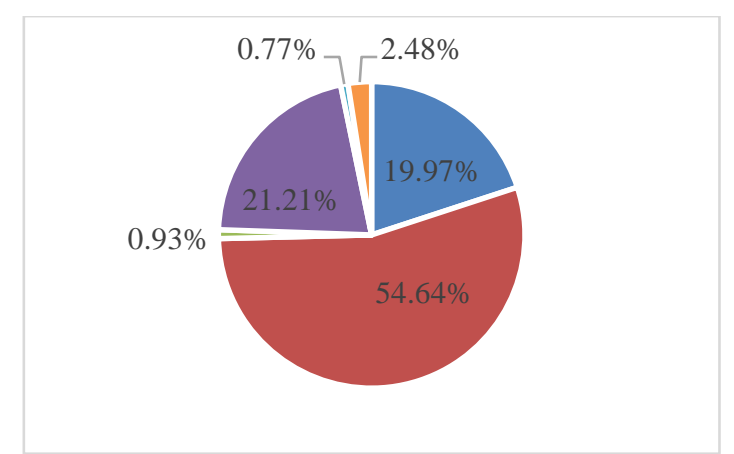

Source: Questionnaire data compiled by the author at the Indonesian Trilingual School in 2018

Fig.2 Distribution of religious beliefs of Chinese descent students in Indonesian Trilingual Schools 
The results show that most Chinese descent students have a clear religious belief. Most students hold religious beliefs, but the proportion of religious factions they convert to is different. Christianity, Catholics, and Buddhism are more common. The proportions are $54.64 \%, 21.21 \%$, and $19.97 \%$ respectively. Indonesian Chinese are more inclined to Western religions for survival and development because of the discriminatory measures under Suharto administration. Due to the deep influence of Western culture, Indonesian Chinese are more likely to choose Christianity and Catholicism. Religious beliefs have intergenerational transmission, ethnic Chinese teenagers follow the ancestors' belief in Western religions. It is worth noting that a small number of Chinese descent students choose Confucianism and Islam, accounting for $0.93 \%$ and $0.77 \%$ of the total. Due to the restoration of faith activities at the end of the 20th century, there were relatively few students who believed in Confucian beliefs; ethnic Chinese still had some beliefs in Islamism. There are also Indonesian Chinese who believe in Hinduism. Affected by the culture of residence place, Chinese in Bali Province of Indonesia are trend to believe in Hinduism. Religious beliefs are of great significance to Indonesian citizens. As a national school, how does the Indonesian Trilingual School implement the religious beliefs of students? To this end, a question was designed.

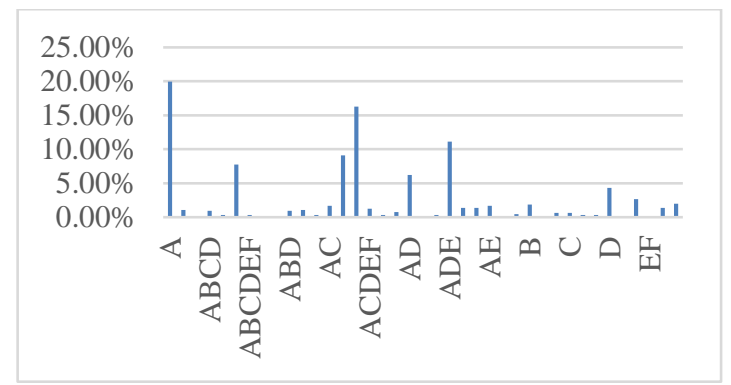

\begin{tabular}{|l|l|l|l|l|l|}
\hline A & ACDE & ADE & ACD & other & total \\
\hline $19.97 \%$ & $16.25 \%$ & $11.15 \%$ & $9.13 \%$ & $43.50 \%$ & $100 \%$ \\
\hline
\end{tabular}

Remarks: A: religious classroom; B: go to religious places; C: read religious textbooks; D: conduct interclass prayers $\mathrm{E}$ : celebrate religious programs

Source: Questionnaire data compiled by the author at the Indonesian Trilingual School in 2018

Fig.3. Religious teaching methods in Indonesian trilingual schools

It can be seen that the religious activities carried out by the Indonesian trilingual schools are diverse. The form is based on basic classroom teaching, combining religious ceremonies, activity celebrations and off-campus practices. Religious learning emphasizes the combination of theory and practice, enabling students to form basic religious beliefs and integrate religious beliefs into their lives. Students' subjective perceptions of learning outcomes can reflect the quality of school teaching activities. When asked about the following question: "In the study of the school, is it helpful for you to understand your own religious beliefs?" The student answers as follows: 


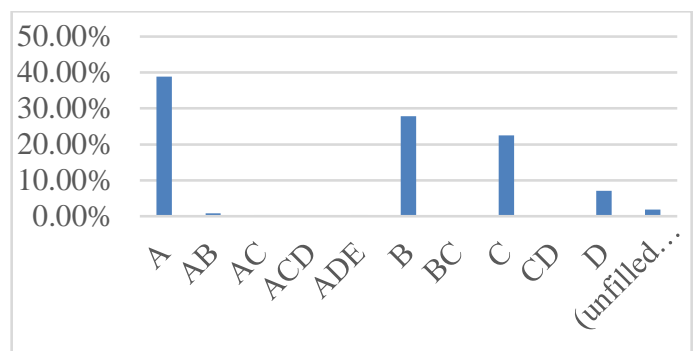

\begin{tabular}{|c|c|c|c|c|c|}
\hline $\mathrm{A}$ & $\mathrm{B}$ & $\mathrm{C}$ & $\mathrm{D}$ & other & total \\
\hline $38.85 \%$ & $27.86 \%$ & $22.45 \%$ & $7.12 \%$ & $3.72 \%$ & $100 \%$ \\
\hline
\end{tabular}

Remarks: A: very helpful; B: help; C: less help; D: no help

Source: Questionnaire data compiled by the author at the Indonesian Trilingual School in 2018

Fig.4. Student Evaluation of Religious Teaching Activities in Indonesian Trilingual Schools

Generally speaking, the trilingual schools play a positive role in the dissemination of religious knowledge and the belief in sublimation. Its teaching results have certain effects, and most students are willing to participate in the religious activities of the school. The student generally believes that the trilingual school is helpful to its own religious beliefs, with a total proportion of $91 \%$. But, the role of religious teaching activities varies from student to student. The proportion of students who think "very helpful" is $38.85 \%$, the ratio of "some help" is $27.86 \%$, and the ratio of "less help" is $22.45 \%$. This data indicates that Indonesian trilingual schools still need to be strengthened in terms of religious teaching methods and teaching diversity. A small number of students (7.13\%) think that they are "not helpful". The trilingual schools have a certain tendency to carry out religious activities on the basis of respecting religious equality, and generally choose Christianity or Catholicism. Because of the distinction between religious beliefs, non-Christian or Catholic students are less affected by religious activities in schools. In the Pelita School, a trilingual school with a Catholic faith, 50\% Buddhist students believe that "school religious activities are not helpful".

\subsubsection{Proficiency in Indonesian language and culture}

Familiarity with the local language and culture is the basic requirement of cultural adaptation, enabling Indonesian Chinese to communicate smoothly with others in their daily lives. The following is an overview of the school's Indonesian language and culture teaching.

\subsubsection{1 using of Indonesian language}

A comprehensive grasp of the local language and its communicative norms is the foundation of social integration. If the language and cultural level of immigrants are close to the main ethnic group, the process of integration and assimilation will be faster[13]. If Chinese descent students choose to use Indonesian and local dialects in most cases, they are deeply involved in the mainstream society in Indonesia. 


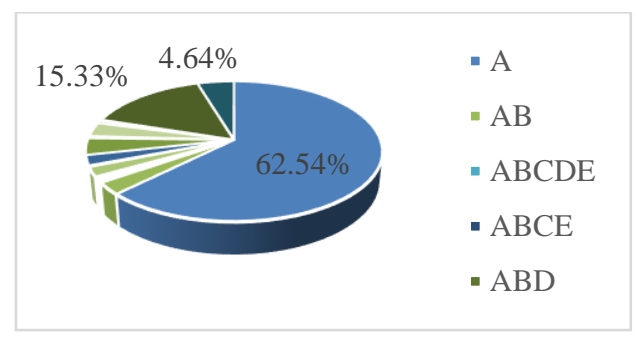

\begin{tabular}{|c|c|c|c|c|c|c|}
\hline $\mathrm{A}$ & $\mathrm{B}$ & $\mathrm{C}$ & $\mathrm{D}$ & $\mathrm{E}$ & other & total \\
\hline $62.54 \%$ & $3.87 \%$ & $3.25 \%$ & $0.62 \%$ & $15.33 \%$ & $14.39 \%$ & $100 \%$ \\
\hline
\end{tabular}

Remarks: A: Indonesian; B: Indonesian dialect; C: Chinese Mandarin; D: Chinese dialect; E: English

Source: Questionnaire data compiled by the author at the Indonesian Trilingual School in 2018

Fig.5.Distribution of common language among Chinese descent students in Indonesian trilingual schools

The main language used by students in the school is Indonesian, with a ratio of $62.54 \%$. The second most frequently used language is English, with a ratio of $15.33 \%$. A small number of students use Indonesian dialect, Mandarin Chinese and Chinese dialect as the common language of the school. A total of $66.41 \%$ of students use official Indonesian language or Indonesian dialects as the primary choice for campus language, indicating that most Chinese descent students have a high degree of language integration. School education promotes students to learn Indonesian in depth. According to the curriculum of the Ministry of Culture and Education of Indonesia, the Indonesian language course is a compulsory course that directly affects the student's academic performance. Therefore, the school attaches great importance to the academic status of Indonesian language and guarantees the quality of teaching in Indonesia. Language learning is inseparable from the influence of the social environment. Students integrate language learning into their lives in a native language context, resulting in a higher practical rate of language learning in Indonesian languages. From the perspective of language usage type frequency, Indonesian language is used most frequently in schools compared to other languages. This highlights the national character of Indonesian three-language school education, namely Indonesian as the first language of teaching.

English is the second language most spoken by students during the school years. The English level of Chinese descent students is generally better. One reason is that Chinese families generally value English learning. The Chinese family believes that learning the international language (English) will help to expand the international perspective of their children and enhance their competitive advantage. The second reason is that Indonesian society is deeply influenced by Western culture. Western cultural works and electronic technology have spread in Indonesia for a long time and in a wide range. Indonesian citizens have a high degree of acceptance of Western things. As far as the status quo of Indonesia's social development is concerned, the English language is widely used in the public sphere of society. Learning English is also a way to adapt to the upper middle class of Indonesia.

\subsubsection{Indonesian cultural cognition}

Language is the carrier of culture. Through the language medium, you can understand the cultural connotation of a specific region. Figure 4 has verified that the students of the trilingual school are proficient in the Indonesian language. On this basis, the students' awareness of Indonesian culture can be seen from Figure 5.

Indonesia has more than 300 ethnic groups, and each one has a splendid ethnic culture. 
The specific ethnic culture reflects the way of thinking and artistic aesthetics of the ethnic group. Indonesian Chinese consciously recognize and appreciate the culture of other ethnic groups is the performance of actively participation in the mainstream society, which is conducive to alleviating the independent and closed inter-ethnic relationship.

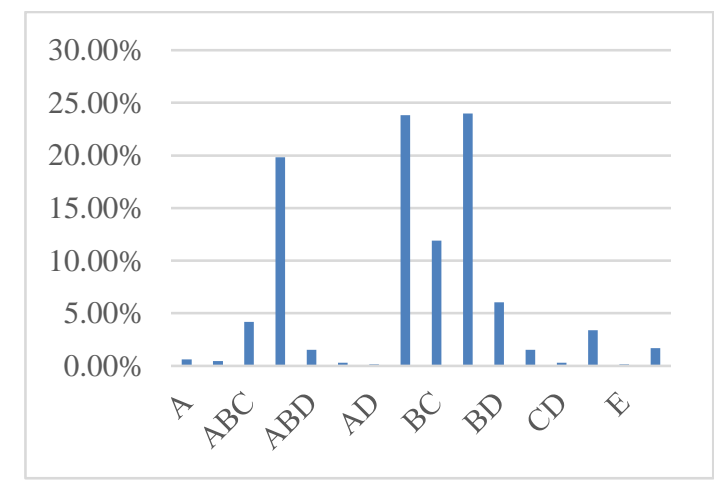

\begin{tabular}{|l|l|l|l|l|l|l|}
\hline BCD & B & ABCD & BC & BD & other & total \\
\hline $23.99 \%$ & $23.84 \%$ & $19.81 \%$ & $11.92 \%$ & $6.04 \%$ & $14.4 \%$ & $100 \%$ \\
\hline
\end{tabular}

Remarks: A, erhu; B, Angklung; C, Gamelan; D, Chinese drum

Source: Questionnaire data compiled by the author at the Indonesian Trilingual School in 2018

Fig.6. Chinese descent students' awareness of mainstream culture in Indonesian trilingual schools

Angklung and Gamelan are popular in Java Island, Indonesia, and are used for religious ceremonies and major festivals. This questionnaire uses Angklung and Gan Melan as representatives of traditional Indonesian musical instruments to examine students' perceptions of traditional culture. According to the survey results, a total of $93.96 \%$ of Chinese descent students know Indonesian traditional instruments, which means that most Chinese descent students in Indonesian trilingual schools generally understand Indonesian traditional culture. During the visit, we learned that Chinese descent students generally acquire mainstream traditional cultural knowledge and can also interpret a variety of Indonesian local art. For example, freshmen in the Medan primary and secondary school perform traditional dances Badin Lin dance at the opening ceremony. A large proportion of Chinese descent students have acquired the common sense of Indonesian culture and tradition, and some Chinese descent students develop their own hobbies and specialties based on the traditional culture. What role does the school play in the process of Indonesian cultural cognition? The questionnaire is mentioned in the seventh question: 


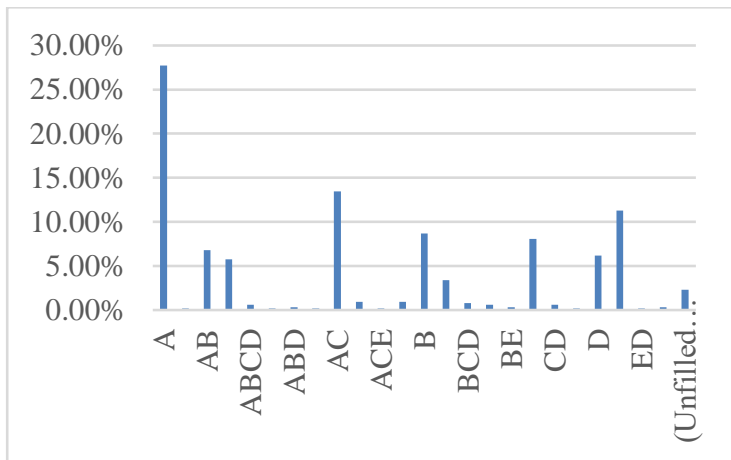

\begin{tabular}{|l|l|l|l|l|l|l|l|l|}
\hline $\mathrm{A}$ & $\mathrm{AC}$ & $\mathrm{E}$ & $\mathrm{B}$ & $\mathrm{C}$ & $\mathrm{AB}$ & $\mathrm{D}$ & other & total \\
\hline $27.71 \%$ & $13.47 \%$ & $11.30 \%$ & $8.67 \%$ & $8.05 \%$ & $6.81 \%$ & $6.18 \%$ & $17.81 \%$ & $100 \%$ \\
\hline
\end{tabular}

Remarks: A,music lesson or dance lesson; B,cultural lesson; C,school celebrations; D,others; e,less contact Source: Questionnaire data compiled by the author at the Indonesian Trilingual School in 2018

Fig.7. Mainstream culture teaching methods in Indonesian three-language schools

From the diversity of answers, we can understand that there are many ways for schools to spread local traditional culture. $27.71 \%$ of students can learn traditional instruments from the classroom; $13.47 \%$ of students are exposed to traditional instruments in classrooms and celebrations; $8.67 \%$ of students express knowledge about traditional instruments from cultural textbooks. The Indonesian Trilingual School promotes students' knowledge and skills in traditional Indonesian folk music through various forms such as art classes, cultural and sports activities, and textbooks. Teaching and literary activities are the main ways for schools to spread local traditional culture.

In addition, among other options, several students mentioned the knowledge of traditional instruments by participating in student associations. Student activities, represented by student societies, play a necessary role in the dissemination of traditional Indonesian folk music. For example, Puhua School students have independently established knowledge, art, and language associations. Each year, the school hosts a cultural show that is self-directed and self-performed by students. Among them, there are many traditional Indonesian dances, musical instruments and songs.

\subsection{Promoting the Inheritance of Chinese Culture}

The Indonesian Trilingual Schools encourage Chinese descent students to inherit traditional Chinese culture while integrating into mainstream society and culture of Indonesia. In order to promote the development of Chinese descendants and build a harmonious relationship between ethnic groups, the Indonesian Trilingual Schools conducts courses and activities on Chinese culture, helps Chinese descent students to inherit Chinese culture, including cultural identity, moral etiquette, language use and art etc.

\subsubsection{Gradually forming Chinese identity}

The ethnic cultural attribute is the "name card" of ethnic Chinese to show their identity, and it is the inexhaustible power to support the continuous development of this ethnic group. Due to the influence of Indonesian history, the ethnic identity of Indonesian Chinese has 
gradually declined. The Indonesian Trilingual School promotes the ethnic identity of Chinese descent students through cultural activities.

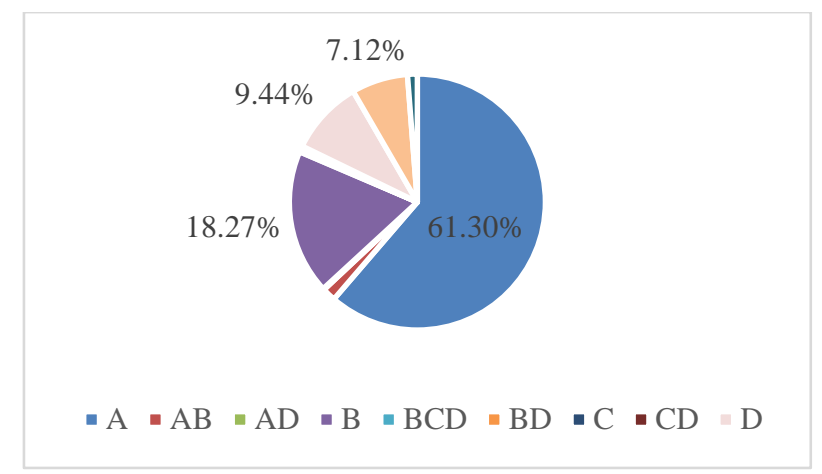

\begin{tabular}{|l|l|l|l|l|l|}
\hline A & B & D & BD & other & total \\
\hline $61.30 \%$ & $18.27 \%$ & $9.44 \%$ & $7.12 \%$ & $3.87 \%$ & $100 \%$ \\
\hline \multicolumn{6}{|c|}{ Remarks: A Chinese; B Java; C, sunda; D; others }
\end{tabular}

Source: Questionnaire data compiled by the author at the Indonesian Trilingual School in 2018

Fig.8. Ethnic Identity of Chinese descent students in Indonesian Trilingual School

From the chart data, Chinese descent students who identify with ethnic identity account for $61.3 \%$ of the total number, and the proportion of students who think they are Javanese is $18.27 \%$, and they think they are $9.44 \%$ of others. Based on this, $20 \%$ of Chinese descent students have no sense of belonging to the Chinese.

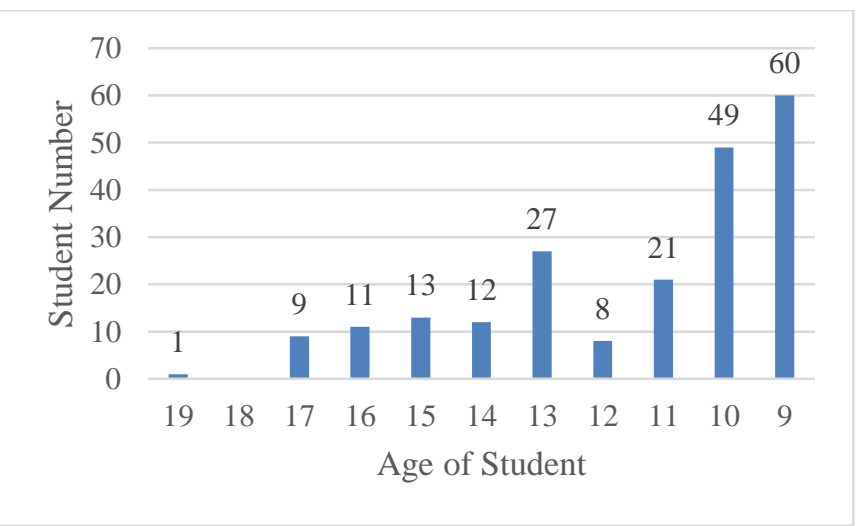

Source: Questionnaire data compiled by the author at the Indonesian Trilingual School in 2018

Fig.9. Age distribution of fuzzy Chinese descent students in Indonesian trilingual school

Though 20\% Chinese descent students of the Indonesian Trilingual Schools have a weak approval for the Chinese ethnic group, it can be seen from Figure 2.2 that the number of students with vague Chinese identity tends to decrease with age. Under the joint promotion of family education, social environment influence, school culture environment and personal physical and mental development, the ethnic identity of Chinese descent students will be enhanced. Second, the students' Chinese identity is fluctuating due to different learning stages. 
At the same time, in the specific learning stage, the characteristics of Chinese identity increase with the growth of grades are increasing year by year. In primary school students between the ages of 9 and 12, the misunderstanding of ethnic identity gradually decreases with the increase of grades.

Among the students aged 13 to 15 in the first year of junior high school stage, the knowledge backgrounds from different schools increase the number of students with vague ideas of Chinese. However, with the deepening of school education, the number of such students has decreased from $27 \%$ to $13 \%$. The high school students gradually develop clear ethnic cognition as they grow older. In the case of the same physical and mental development of students, the Chinese cultural education in Indonesian trilingual schools indirectly enhances the ethnic identity of students. The Trilingual School offers Chinese-related activities related to Chinese culture, deepening students' impressions of Chinese cultural symbols, and cultivating and maintaining students' belonging to the Chinese. Based on this, the low-age students of Indonesian trilingual schools have low Chinese identity. With the education of the school and the development of personal and physical development, the Chinese identity of the students is gradually confirmed.

\subsubsection{Developing a good moral quality}

Treating with courtesy is a fine tradition of the Chinese nation. Cultivating students' good behavioral norms and inheriting the fine traditional Chinese ethics is part of the function of moral education in Indonesian trilingual schools. The school achieves the goal of moral education through various teaching methods.

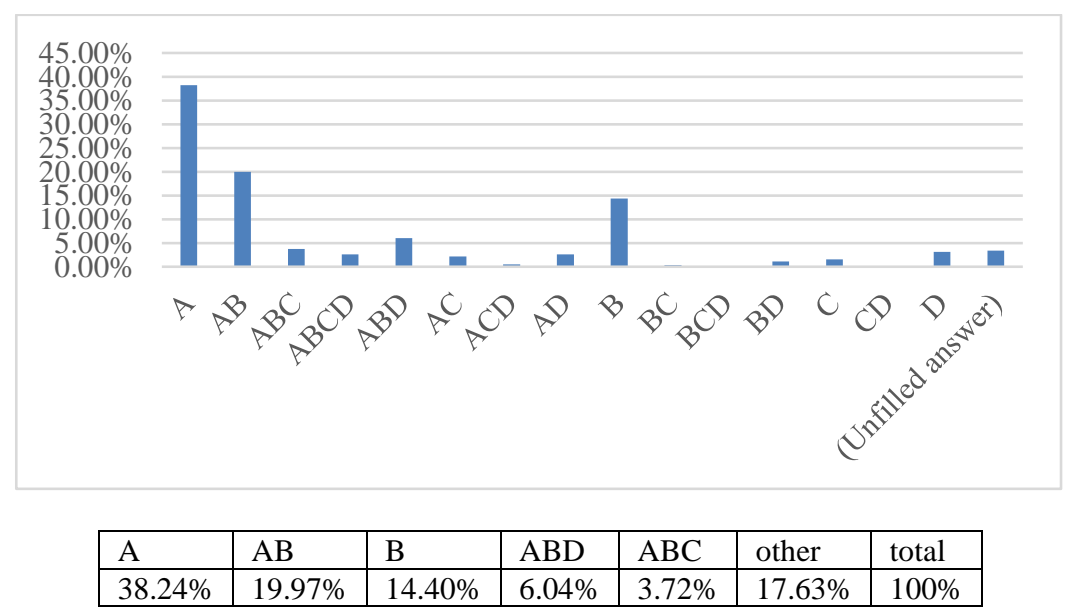

Remarks: A, teacher's words and deeds; B, moral education; C, etiquette contest; D, textbooks; Source: Questionnaire data compiled by the author at the Indonesian Trilingual School in 2018

Fig.10. Indonesian trilingual moral education pathway

$38.24 \%$ of the students choose to enhance their morality through the teacher's words and deeds. $19.97 \%$ of the students believe that the teacher's words, deeds and moral education courses of the trilingual school teachers play an important role in shaping their own moral cultivation; in addition, reading textbooks and participating in the etiquette contest are the integral parts of school moral education. From the perspective of selection, the most influential factors affecting students' moral cultivation are school teachers. Teachers and 
students are in frequent contact, and their personality quality and behavioral habits become the objects of students' emulation. The teachers of the trilingual school hold a good teacher's morality and have a strong sense of responsibility. This is why most students choose to enhance their morality through the teacher's words and deeds. In addition, from the diversity of students' answers, it reflects the school's multi-category forms of moral education, such as moral education curriculum, etiquette contest, self-made moral education textbooks, and moral education practice. The teaching of "Discipline Rules" (《弟子规》)is a distinctive feature of Chinese moral education in trilingual schools. Most of the trilingual schools require students to recite the "Discipline Rules" from the primary school, and strengthen the students' mastery of the discipline through Chinese courses, moral education courses and cultural performances.

What is the impact of schools' moral education practice on students' moral behavior? The questionnaire is reflected by setting questions about respecting teachers. As for the question "When you meet the teacher in the corridor, will you take the initiative to ask?", $76.78 \%$ of the students chose to say hello to the teachers they met very enthusiastically; $13.47 \%$ of the students treated the teachers more casually; $4.64 \%$ students selectively say hello to the teacher, and less than $1 \%$ of the students feel that they have not seen the teacher. The results show that the majority of Indonesian trilingual school students have developed a good traditional morality, showing politeness and respecting the teachers. Most of the teachers and students in Indonesian trilingual schools are good friends, and the relationship is harmonious.

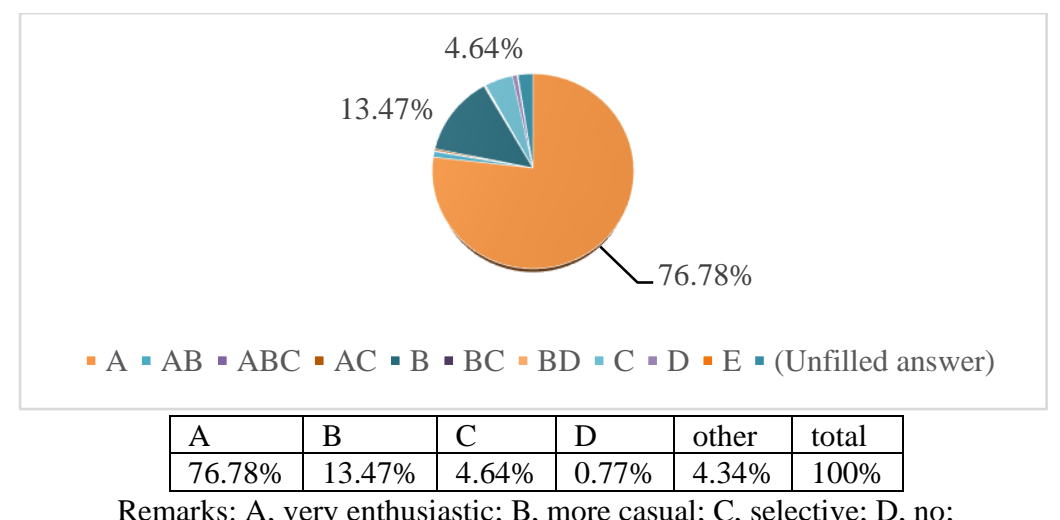

Source: Questionnaire data compiled by the author at the Indonesian Trilingual School in 2018

Fig.11. Morality of Chinese descent students in Indonesian trilingual school

\subsubsection{Learning Chinese Language and culture}

Mastering Chinese language skills is an advantage of Chinese self-development as well as the cultural need of ethnic development. Having a good learning motivation is a prerequisite for ensuring the quality of learning. 


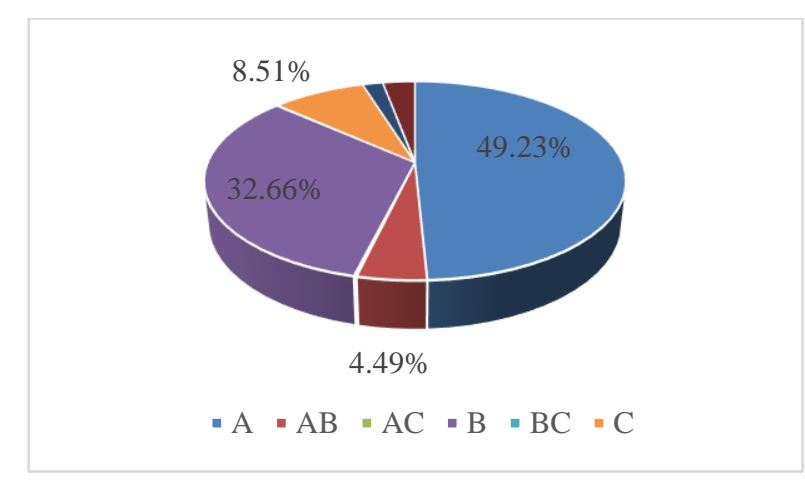

\begin{tabular}{|l|l|l|l|l|}
\hline A & B & C & other & total \\
\hline $49.23 \%$ & $32.66 \%$ & $8.51 \%$ & $9.6 \%$ & $100 \%$ \\
\hline
\end{tabular}

Remarks: A. It is good for future work; B. As a Chinese, you should understand; C, no need; Source: Questionnaire data compiled by the author at the Indonesian Trilingual School in 2018

Fig.12. Motivation of Chinese descent students in Indonesian Trilingual School

For the question "Do you need to learn Chinese?", we found that $49.23 \%$ of students are willing to learn Chinese, and know that the language of Chinese is helpful for future work; $32.66 \%$ of students said that they should learn Chinese and know their own ethnic culture as an ethnic Chinese; $8.51 \%$ of students believe that there is no need to learn Chinese. So we conclude that most Indonesian Chinese believe that learning Chinese is necessary. What explains this phenomenon?

First of all, the younger generation attaches great importance to the economic value of Chinese language, comparing with motivation of ethnic group belonging for their parents and ancestors.

It can be seen that the young Chinese descent students showed a tendency to downplay ethnic identity. One student in the first year of junior high school said: "Learning Chinese is very important for us ethnic Chinese, but it is not important for individuals."[14]. The formation of Chinese learning motivation is not only related to language value, but also inseparable from the influence of social and cultural environment and personal values. At the same time, the size of students' Chinese motivation is related to age. Students in primary school and high school have significant differences in Chinese motivational cognition. As shown in Figure 13, the number of primary school students who have no learning motivation is more than twice that of high school students. But most high school students are willing to learn Chinese and recognize the ethnic and economic value of Chinese learning. It can be seen that with the increase of age and the expansion of vision, the recognition of Chinese value will be enhanced. 


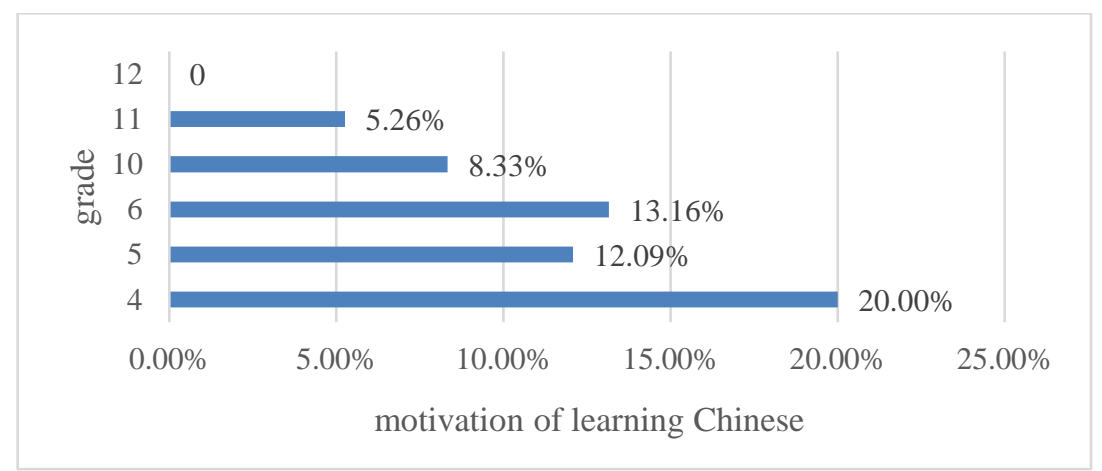

Source: Questionnaire data compiled by the author at the Indonesian Trilingual School in 20181

Fig.13. Differences in Chinese Learning Cognition between Chinese and High School Students in Chinese Learning

The most fundamental goal of Chinese education is to enable Chinese descent students to learn Chinese and communicate with Chinese[15]. The trilingual schools focus on cultivating students' Chinese language skills, such as listening, speaking, reading and writing etc..

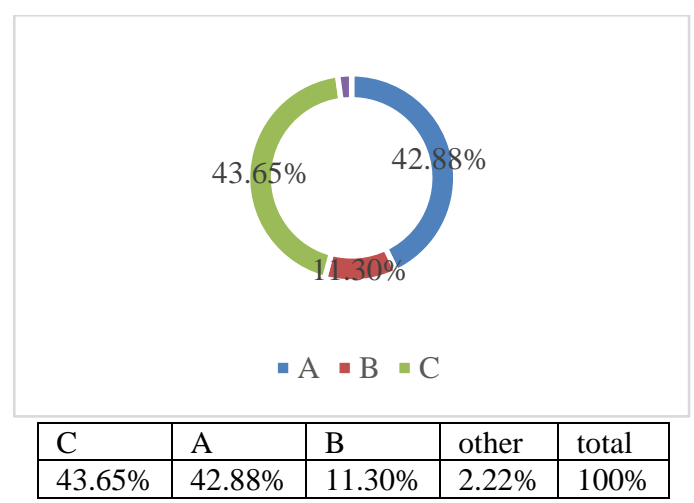

Remarks: A, like; B, do not like; C, depending on the situation;

Source: Questionnaire data compiled by the author at the Indonesian Trilingual School in 2018

Fig.14. Student Evaluation of Chinese Classroom in Indonesian Trilingual School

What's the attitude of the students about Chinese teaching? We found that the school's teaching level is directly reflected in the students' attitude towards the course $43.65 \%$ of the students chose to learn according to the Chinese classroom teaching situation, $42.88 \%$ of the students like Chinese courses, and $11.3 \%$ of the students do not like Chinese courses.

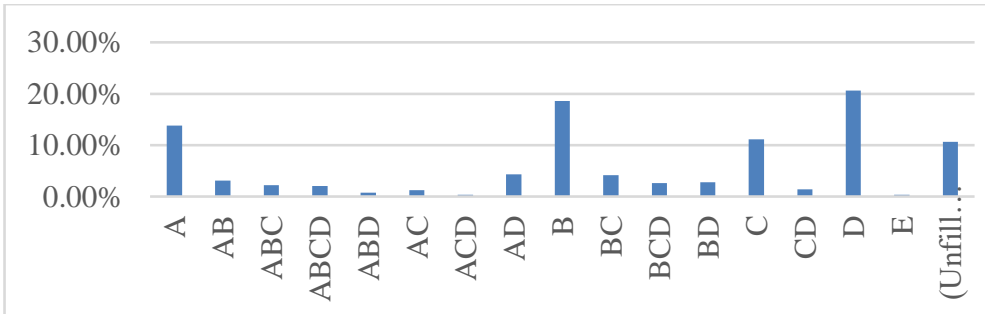




\begin{tabular}{|l|l|l|l|l|l|}
\hline $\mathrm{D}$ & $\mathrm{B}$ & $\mathrm{A}$ & $\mathrm{C}$ & other & total \\
\hline $20.59 \%$ & $18.58 \%$ & $13.78 \%$ & $11.15 \%$ & $35.9 \%$ & $100 \%$ \\
\hline
\end{tabular}

Remarks: A, the teacher-student relationship is harmonious; $\mathrm{B}$, the curriculum is diverse; $\mathrm{C}$, the content of the textbook is interesting; $d$, has a certain Chinese foundation

Fig.15. Advantages of Chinese Learning for Chinese descent students in Indonesian Trilingual Schools

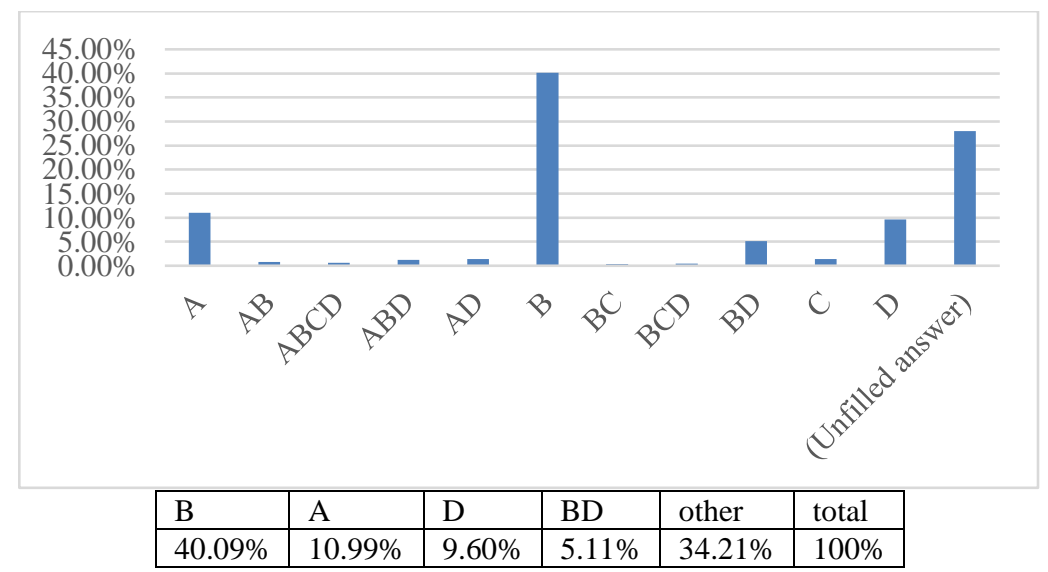

Remarks: A, Chinese classroom interaction is not strong; B, Chinese is difficult; C, no Chinese learning motivation; D, Chinese textbooks are off the actual

Source: Questionnaire data compiled by the author at the Indonesian Trilingual School in 2018

Fig.16. Disadvantages of Chinese Learning for Chinese descent students in Indonesian Trilingual

$$
\text { Schools }
$$

What are the advantages and disadvantages of Chinese classes from the subjective perspective of the students? Figure 16 reflects the favorable conditions for Chinese teaching in Indonesian trilingual schools. First, the Chinese language learning atmosphere in the trilingual school is good, $20.59 \%$ of the students have a certain Chinese foundation; secondly, the trilingual school offers a diversified Chinese curriculum to meet the needs of individualized development of students; the third is the harmonious relationship between students and teachers. However, the Indonesian trilingual schools still face some challenges ,such as he limited resources, unattractive classroom and teaching materials, and improvement of teaching methods etc. Through the course study, students' Chinese communication skills are available in Figure 17.

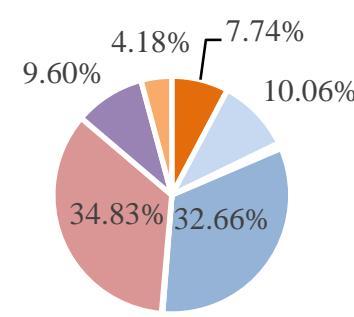

$-\mathrm{A}=\mathrm{B}=\mathrm{BC}-\mathrm{BD}=\mathrm{C}=\mathrm{CD} \approx \mathrm{D} \approx \mathrm{E}$ 


\begin{tabular}{|l|l|l|l|l|l|l|}
\hline $\mathrm{D}$ & $\mathrm{C}$ & $\mathrm{B}$ & $\mathrm{E}$ & $\mathrm{A}$ & other & total \\
\hline $34.83 \%$ & $32.66 \%$ & $10.06 \%$ & $9.6 \%$ & $7.74 \%$ & $5.11 \%$ & $100 \%$ \\
\hline
\end{tabular}

Remarks: A, very fluent; B, basic ability; C, general; D, only one point; E, can not

Source: Questionnaire data compiled by the author at the Indonesian Trilingual School in 2018

Fig.17. Chinese communicative competence of Chinese descent students in Indonesian trilingual school

$34.83 \%$ of the students said that they can only speak a little Chinese in the communication; $32.66 \%$ of the students said that the Chinese communication ability is general; $10.6 \%$ of the students said that they can basically communicate in Chinese; $7.6 \%$ of the students said that they can communicate fluently in Chinese. Chinese descent students already have a basic knowledge of Chinese, but they still need to continue learning if they want to fully master Chinese. The Chinese communicative ability of Chinese descent students varies between individuals and between schools. Students with good family Chinese atmosphere have strong Chinese communication ability;in schools with sufficient Chinese resources and emphasis on Chinese teaching, the vast majority of students can master Chinese communication skills.

Language learning can not be separated from the cultural environment, cultural factors guarantee the appropriateness of language use[16], help to understand a second language. The Chinese language teaching and activities permeate Chinese culture and contribute to the learning outcomes of Chinese descent students.

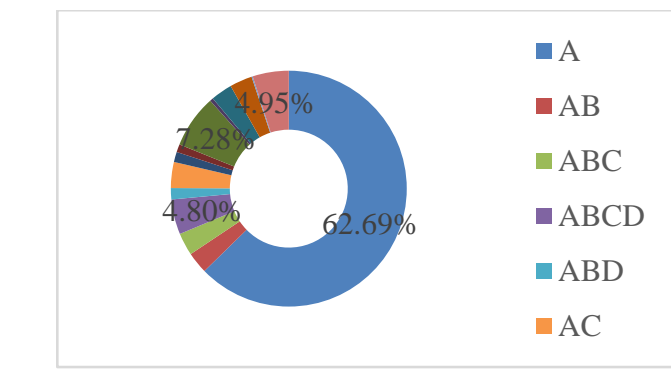

\begin{tabular}{|l|l|l|r|l|l|}
\hline A & B & blank & ABCD & other & total \\
\hline $62.69 \%$ & $7.82 \%$ & $4.95 \%$ & $4.8 \%$ & $19.74 \%$ & $100 \%$ \\
\hline
\end{tabular}

Remarks: A, traditional festivals; B, paper-cut, calligraphy; C, Hanfu,, cheongsam; D, disciples

Source: Questionnaire data compiled by the author in Indonesian trilingual school in 2018

Fig.18. Chinese-Cultural Cognition of Chinese descent students in Indonesian Trilingual Schools

Chinese descent students have a preliminary understanding of traditional Chinese costumes, crafts and ethics. According to the survey results, traditional Chinese festivals are the cultural symbols most familiar to Chinese descent students, with a ratio of $62.44 \%$. But Chinese descent students in Indonesian trilingual schools have a partial understanding of Chinese culture and lack systematic understanding.

Due to the limited duration of language teaching in schools, students should also establish a goal of learning Chinese for life in order to achieve the purpose of inheriting Chinese culture. 


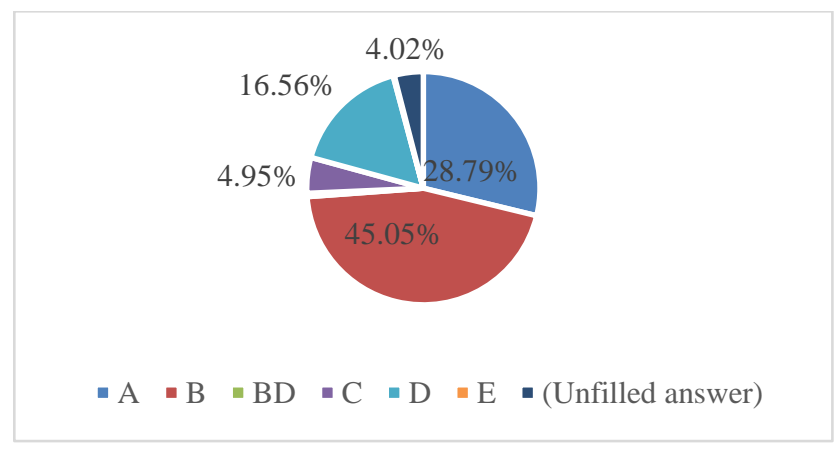

\begin{tabular}{|l|l|l|l|l|l|}
\hline $\mathrm{B}$ & $\mathrm{A}$ & $\mathrm{D}$ & $\mathrm{C}$ & other & total \\
\hline $45.05 \%$ & $28.79 \%$ & $16.56 \%$ & $4.95 \%$ & $4.61 \%$ & $100 \%$ \\
\hline
\end{tabular}

Remarks: A, will; B, possible; C, no; D, do not know

Fig.19. Chinese-speaking students of Indonesian trilingual school will learn Chinese in the future

According to the survey results, $28.79 \%$ of the students are very determined to learn Chinese in the future; these students maintain good Chinese language motivation, and these students are mainly concentrated in high school. This indicates that the Indonesian Trilingual School has stimulated some Chinese descent students to learn Chinese interest and cultivate higher-level Chinese talents through education; $45.05 \%$ of students said that Chinese language learning depends on future development; $4.95 \%$ of students will not learn Chinese in the future. Most Chinese descent students have a vague attitude towards continuing Chinese learning, but they do not deny the possibility of learning Chinese in the future. This shows that students have a positive attitude towards Chinese language value.

\section{Conclusion}

During the period of democratic reform in Indonesia, more than 70 trilingual schools have been setup, which reflect the changes in Chinese education in the new era. Based on the questionnaire survey and interview conducted in the trilingual schools, we verified the following research hypothesis: Indonesian trilingual schools can play an important role in social integration and cultural Inheritance for the Chinese descent students, though they have different degrees of integration into the mainstream and cultural inheritance depending on their age, school and region.

On the one hand, we find that multilingual classroom teaching, practical activities and cultural environment influence in the Indonesian trilingual schools are the important variables of affecting the integration of the ethnic Chinese into the mainstream and the inheritance of Chinese culture. The Indonesian trilingual schools conduct moral education through classroom teaching and extracurricular activities, and deepens the integration of students into the mainstream society by strengthening the national education and religious education system. First of all, it is expressed in national identity. From the political identity, the new generation of ethnic Chinese recognizes the Indonesian state, and have a strong sense of belonging to and pride of the country. The Trilingual schools are committed to national education and makes full use of the social environment to strengthen students' national awareness. Followed by religious beliefs, according to the needs of national cultural development, Indonesian trilingual 
schools have defined the direction of religious development, set up relevant religious courses on campus, organize religious extracurricular activities, and infiltrate religious rituals into student life and study, and promote students' religious beliefs. As for the cultural identity, the students have a comprehensive grasp of Indonesian language and local dialects, gradually integrated into the local community while learning local customs, lifestyle and artistic aesthetics. The reasons for the change are the roles of Indonesian Chinese schools, which offer special cultural courses with local characteristics , and encourage the combination of knowledge culture and practical life, conducting outdoor cultural tours, which enable students to understand the charm of local culture.

On the other hand, Chinese descent students inherit Chinese culture to some extent though they learned the mainstream culture greater .Indonesian trilingual schools encourage Chinese descent students to inherit Chinese culture through the following measures: diversified classroom teaching, good learning atmosphere, and Chinese-themed activities. The teaching activities are embodied in the following aspects: First, the school encourages gratitude moral education in practical teaching, which affects students' moral concepts and behaviors. Second, the school conducts language and culture teaching, and combines cultural environment and classroom activities to enable students to learn Chinese language and culture. Chinese language and culture teaching courses are diversified, flexible in class and teacher's patient teaching, to promote students' interest in learning, and to master Chinese language communication and culture. However, the Chinese language education is still facing some challenges, such as less Chinese context, insufficient professional teachers, low localization of the Chinese textbooks, and some misperceptions about the trilingual schools etc. In terms of the overall Chinese level, the students have the best Chinese listening skills and can speak and communicate with simple Chinese, but the ability to read and write needs to be improved.

\section{References}

[1] John W. Berry, Jean S. Phinney, David L. Sam, Paul Vedder : Immigrant Youth in Cultural Transition

[2] Acculturation, Identity, and Adaptation Across National Contexts, New York: Psychology Press, 2014.

[3] WangYu, LiuYan: “The Connotation and Function of Bilingual Education”, Educational Review, Volume 1, 2006.

[4] LiuYan: "The Culture Education Attribution of the National Identity Construction of Thai Multilingual school-A Case Study of the DaZhong School in Chon Buri”, Master thesis, Southwest University, 2018.

[5] Zhuangzhihui, LiuYirong: "The Connotation Overseas Chinese Education and the Realization Path of its Cultural Identity Function", Research on Fujian Education, Volume 5, 2012.

[6] LiuYirong, "Acculturation and Chinese Language Education in Malaysia", Journal of Southwest University for Nationalities, Volume 12, 2004.

[7] Valerie Miller Maloof, Donald L. Rubin \& Ann Neville Miller : Cultural Competence and Identity in Cross-cultural Adaptation: The Role of a Vietnamese Heritage Language School, International Journal of Bilingual Education and Bilingualism, Volume 9, 2006 - Issue 2.

[8] NAMu-han: "The Cultural Education of Ethnic Traditions in the Constructionist Perspective", Journal of Yunnan Nationalities University, Volume 3, 2009. p150-p153.

[9] HUANG Kunzhang,The History of Chinese Language Education in Indonesia, Beijing:Foreign Language Teaching and Research Press,2007.

[10] "Lin Lin inspector met with Chen Youming, President of the Indonesian Trilingual School Association”, http://www.qb.gd.gov.cn/news2010/201807/t20180702_953721.htm, Guangdong 
Overseas Chinese Network, March 19, 2019.

[11] Questionnaire survey of the Chinese Language Course of the Trilingual School in Indonesia in 2018.

[12] "Optimizing Teaching in the Exchange of Experiences - Seminar on Indonesian Trilingual Schools",http://surabaya.mofcom.gov.cn/article/jmxw/201901/20190102828158.shtml,Indonesia n News, July 25, 2018,

[13] "Construction Five Principles Connotation", http://www.guojiribao.com/shtml/gjrb/20181101/1191115.shtml, International Daily, January 27, 2019.

[14] Liang Maoxin: "Research on Modern European and American Immigrants and Ethnic Diversity" Beijing: The Commercial Press, 2011, p. 409.

[15] Interview with Chinese Director Xi at Puhua 1 School on August 15, 2018

[16] In July 2018, an interview was conducted with the student hx at the Pelita School in Indonesia.

[17] Zhang Jiancheng: "Chinese Education and Chinese Language and Culture Communication", Beijing: China Social Sciences Press, 2016 edition, p. 109.Ibid. 